\section{Commentary: What matters is what you do, not what you use}

\author{
Anthony L. Estrera, MD
}

First described in the 1970s, the basic tenets for the management of infective endocarditis (IE) include correction of the hemodynamic abnormality, restoration of ventricular/ arterial continuity, appropriate antibiotic treatment, and thorough debridement of all infected tissue. ${ }^{1}$ Although these goals remain the pillars of IE management, the Society of Thoracic Surgeons database indicates that early mortality persist at $10 \%$-with more than $20 \%$ mortality when prosthetic valve endocarditis occurs. ${ }^{2}$ What contributes to this mortality is more related to patient comorbidities and the infectious pathology than the type of prosthesis used. However, questions endure.

In fact, recent expert consensus guidelines from the American Association for Thoracic Surgery states that "choice of valve (mechanical or tissue prosthesis) should be based on normal criteria" and that with more root destruction requiring root reconstruction, "using an allograft may be beneficial, but a prosthetic bioroot or prosthetic valved conduit ... are acceptable alternatives, with choice guided by surgeon training and experience". 3

Clemence and coleagues ${ }^{4}$ report a University of Michigan team's experience with aortic valve IE examining the use of stented versus stentless prosthesis for the replacement from 1998 to 2017. From a total of 299 patients, 265 patients over a 20-year period were divided into 97 stented patients $(37 \%)$ and $168(63 \%)$ stentless patients. In all, 34 patients who had undergone homograft replacement were excluded. The authors demonstrated commendable results, with an early mortality of $4 \%$ for the stented

\footnotetext{
From the Department of Cardiothoracic and Vascular Surgery, McGovern Medical School at The University of Texas Health Science Center at Houston and Memorial Hermann Hospital, Houston, Tex.

Disclosures: Dr Estrera is a consultant for WL Gore \& Associates.

The Journal policy requires editors and reviewers to disclose conflicts of interest and to decline handling or reviewing manuscripts for which they may have a conflict of interest. The editors and reviewers of this article have no conflicts of interest.

Received for publication Sept 17, 2020; revisions received Sept 17, 2020; accepted for publication Sept 18, 2020; available ahead of print Sept 28, 2020.

Address for reprints: Anthony L. Estrera, MD, Department of Cardiothoracic and Vascular Surgery, McGovern Medical School at UTHealth, 6400 Fannin St, Suite 2850, Houston, TX 77030 (E-mail: Anthony.L.Estrera@uth.tmc.edu).

J Thorac Cardiovasc Surg 2022;164:489-90

$0022-5223 / \$ 36.00$

Copyright (c) 2020 by The American Association for Thoracic Surgery

https://doi.org/10.1016/j.jtcvs.2020.09.081
}

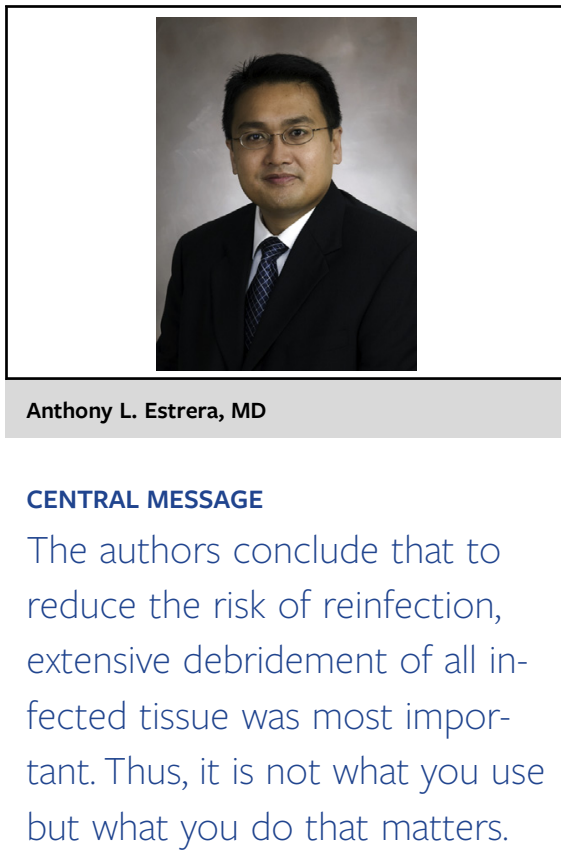

group and $6 \%$ for the stentless group. Cumulative incidence of reoperation at 10 years was just $12 \%$ in the stented group and $3.4 \%$ in the stentless group-with more recurrent endocarditis observed in the stented group $(<1$ year) but more structural valve degeneration in the stentless group $(>8$ years).

This current study comes on the heels of recently published work in which this University of Michigan group analyzed a larger cohort of patients with IE (1996 to 2017) to determine whether IE with associated aortic root abscess influenced outcomes. ${ }^{5}$ The study examined $336 \mathrm{pa}-$ tients divided into 179 root abscess patients compared with 157 no-root abscess patients. They found no significant difference in early mortality $(8.4 \%$ vs $3.8 \% ; P=.11$, respectively). In examining both reports, a few observations should be highlighted:

1. The University of Michigan group appears to prefer the stentless prosthesis for IE-especially when more intensive pathology was encountered. They cite lower cost (than homograft), off-the-shelf availability, familiarity with full root and modified inclusion techniques, better hemodynamic parameters in the small annulus, and less fabric material (than with a stented valve), potentially decreasing the susceptibility to recurrent infection (not substantiated).

2. Even in this younger cohort (aged 50 years), very few mechanical valves were used $(<5 \%)$. 
3. In patients without aortic root abscess, aortic root procedures were performed $46 \%$ of the time-speaking to the surgeons' comfort level with aortic root procedures.

4. In the current report, the use of homograft was excluded. The long-term outcomes would have been interesting to see.

5. Presence of root abscess or type of prosthesis made no difference in early or late outcomes after surgical management of IE.

The authors are to be applauded for their results in a complex patient population. It should also be recognized that the commendable results were likely due to the most important variables never included in statistical analysis; that is, surgeon skill and experience. In the end, the authors appropriately conclude that to reduce the risk of reinfection, "extensive and thorough debridement of all infected tissue"-not the type of prosthesis—was the most important factor. Thus, it is not what you use but what you do that matters.

\section{References}

1. Stinson EB, Copeland JG, Shumway NE. Operative treatment of active endocarditis. J Thorac Cardiovasc Surg. 1976;71:659-65.

2. Savage EB, Saha-Chaudhuri P, Asher CR, Brennan JM, Gammie JS. Outcomes and prosthesis choice for active aortic valve infective endocarditis: analysis of the Society of Thoracic Surgeons adult cardiac surgery database. Ann Thorac Surg. 2014;98:806-14.

3. AATS Surgical Treatment of Infective Endocarditis Consensus Guidelines Writing Committee, Pettersson GB, Coselli JS, Hussain ST, Griffin B, Blackstone EH, et al. 2016 the American Association for Thoracic Surgery (AATS) consensus guidelines: surgical treatment of infective endocarditis: executive summary. J Thorac Cardiovasc Surg. 2017;153:1241-58.e29.

4. Clemence J, Caceres J, Ren T, Wu X, Kim KM, Patel HJ, et al. Treatment of aortic valve endocarditis with stented or stentless valve. J Thorac Cardiovasc Surg. 2022;164:480-7.e1.

5. Yang B, Caceres J, Farhat L, Le T, Brown B, St Pierre E, et al. Root abscess in the setting of infectious endocarditis: short- and long-term outcomes. J Thorac Cardiovasc Surg. April 13, 2020 [Epub ahead of print].
See Article page 480.

\section{Commentary: Regression or progression: Hominum, bovinum, porcinum?}

\author{
Thomas G. Gleason, MD, MS
}

Clemence and colleagues ${ }^{1}$ are to be congratulated for their report in this month's Journal of the University of Michigan's experience with aortic valve endocarditis using either a stented or a stentless (Freestyle; Medtronic, Inc, Minneapolis, Minn) prosthesis. This report mimics another recent study in which they compared those with and without a

From the Division of Cardiac Surgery, Brigham and Women's Hospital and Harvard Medical School, Boston, Mass.

Disclosures: Dr Gleason serves on a Medical Advisory Board for Abbott without significant remuneration.

The Journal policy requires editors and reviewers to disclose conflicts of interest and to decline handling or reviewing manuscripts for which they may have a conflict of interest. The editors and reviewers of this article have no conflicts of interest.

Received for publication Oct 3, 2020; revisions received Oct 3, 2020; accepted for publication Oct 5, 2020; available ahead of print Oct 10, 2020.

Address for reprints: Thomas G. Gleason, MD, MS, Division of Cardiac Surgery, Brigham \& Women's Hospital, 75 Francis St, Boston, MA 02115 (E-mail: tgleason@bwh.harvard.edu).

J Thorac Cardiovasc Surg 2022;164:490-2

0022-5223/\$36.00

Copyright (c) 2020 by The American Association for Thoracic Surgery

https://doi.org/10.1016/j.jtcvs.2020.10.013
Check for updates

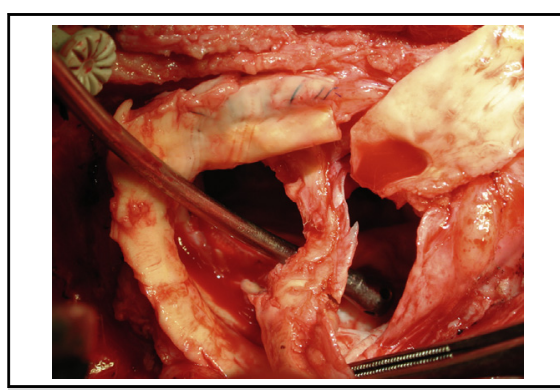

Aortic annular abscess communicating into the right atrium-prosthetic valve removed.

CENTRAL MESSAGE

Stentless valves, stented valves, and homografts all have a relevant role in the surgical management of endocarditis depending on largely on the degree of tissue invasion requiring reconstruction.

root abscess, treated predominantly with either a stented or stentless bioprosthesis. ${ }^{2}$ These reports are similar in that they cover the same time period and included largely the same patients. Notably, their primary conclusions were also essentially identical: emphasizing the value of 